\title{
Diel feeding intensity and daily ration in the anchovy Engraulis encrasicolus in the northwest Mediterranean Sea during the spawning period
}

\author{
Sergi Tudela*, Isabel Palomera \\ Institut de Ciències del Mar (CSIC), Plaça del Mar s/n, E-08039 Barcelona, Spain
}

\begin{abstract}
The first evaluation is presented of the daily ration and daily stomach fullness pattern in the European anchovy Engraulis encrasicolus under natural conditions in the western Mediterranean Sea. The results indicated a pattern of daytime feeding, with minimum stomach fullness values between 03:45 and 05:40 h and maximum values between 17:06 and 18:13 h. The daily ration of food ingested was $3.9 \%$ of individual weight $\left(34.1 \mathrm{cal} \mathrm{g}^{-1}\right)$, appreciably lower than the value reported for this same species in the Black Sea but in good agreement with estimates for other species of the genus Engraulis.
\end{abstract}

KEY WORDS: Anchovy - Engraulis encrasicolus · Feeding · Daily ration - NW Mediterranean

\section{INTRODUCTION}

Studies of the daily food ration and daily stomach fullness pattern in the natural environment are basic tools applied in elucidating the autecology of fish species. Determinations of the daily ration at sea have been carried out in many cases for the purpose of validating bioenergetic models constructed to a greater or lesser extent on the basis of information collected experimentally in the laboratory. Accordingly, some studies have focused on the level of agreement between model estimates and real field or experimental values (Angelescu \& Anganuzzi 1986, Arrhenius \& Hansson 1994). In like manner, a detailed understanding of feeding intensity over a yearly cycle could be used to develop more realistic bioenergetic models that contemplate real annual consumption under natural conditions.

Determining the daily ration for pelagic fish species in the field raises numerous practical difficulties, and for that reason such studies have been infrequent. The need for highly comprehensive sampling to provide information on the daily cycle of stomach fullness is

•E-mail: studela@masagran.icm.csic.es coupled with the need to establish the instantaneous gastric evacuation rate, which in turn often entails handling live individuals taken directly from the natural environment for experimental purposes.

The feeding ecology of the European anchovy Engraulis encrasicolus has only been studied in some detail in the region of the Black Sea and the Sea of Azov, chiefly during the spawning period. Several studies (Mikhman \& Tomanovich 1977, Sirotenko \& Danilevskiy 1978, Bulgakova 1993a) described the daily feeding pattern of the European anchovy. Other authors (Okul 1941, Nikitin 1946, Sirotenko \& Danilevskiy 1978) experimentaily determined the daily ration with the Bajkov (1935) method, based on a linear model of digestion. That model has today been superseded by widespread acceptance of the exponential model proposed by Elliott \& Persson (1978). Bulgakova (1993b) carried out the only assessment of the daily ration of the European anchovy which applied the exponential model of digestion, employing data collected in the Black Sea during the spawning periods from 1987 to 1990. The results suggested a daily ration value several times higher than the estimates calculated in previous studies based on the model of Bajkov (1935). Angelescu \& Anganuzzi 


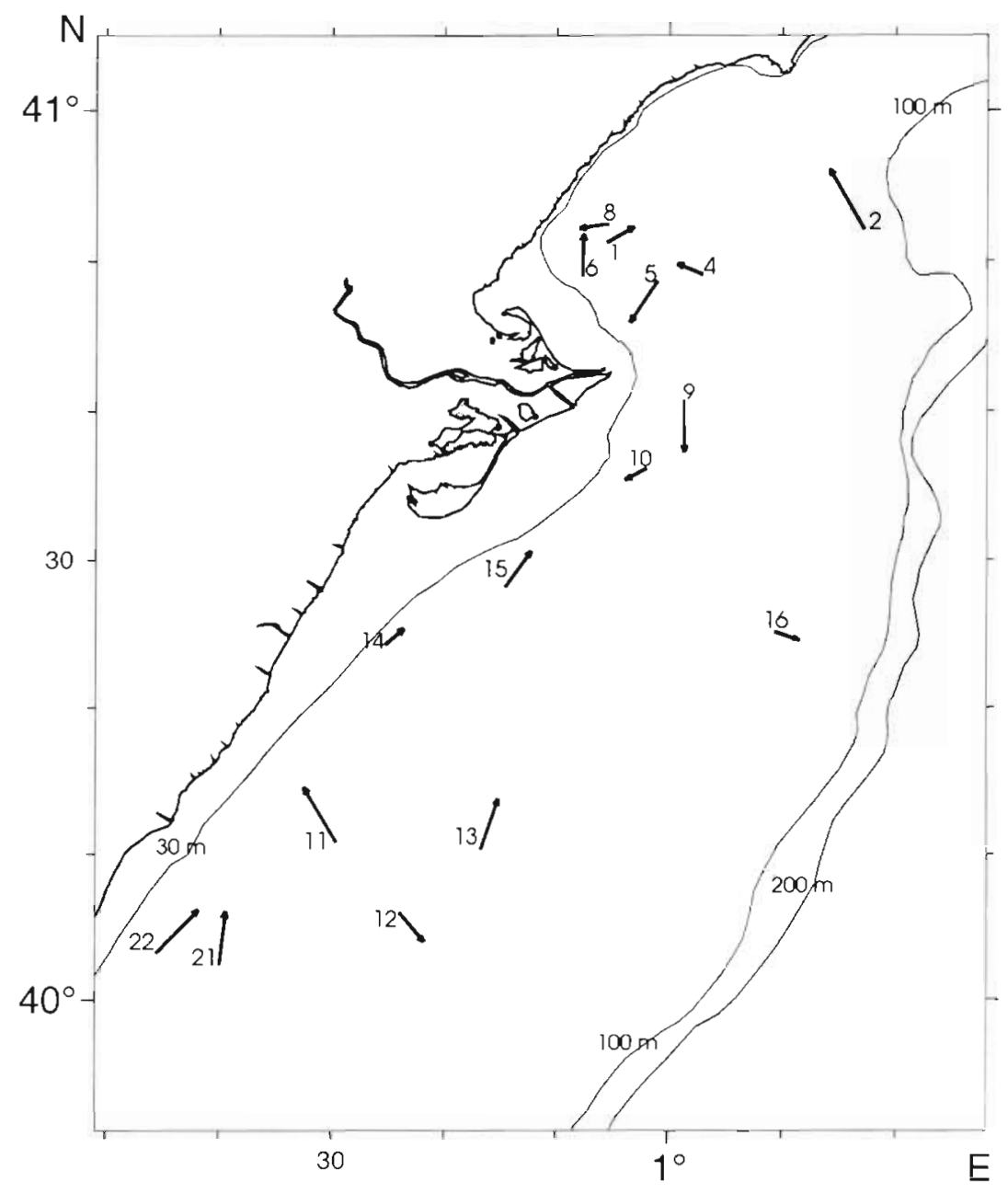

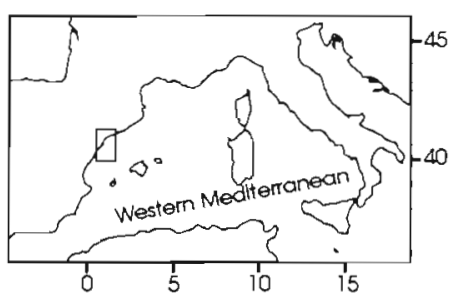

Fig. 1 Location of trawls made to capture anchovies off the coast of Catalonia, Spain (NW Mediterranean) in May 1994 Arrows indicate the ship route during each trawl
(1986) estimated the daily ration for a congeneric species, Engraulis anchoita, at sea during the period of highest consumption, also applying the exponential model of digestion.

This paper presents the first evaluation of the daily ration in the European anchovy under natural conditions in the western Mediterranean Sea. In this area, the species is believed to play an important role in the flow of energy between zooplankton and higher levels of the trophic chain and is the target species of an important fishing industry. The results obtained were compared to the findings of Bulgakova (1993b), who reported values much higher than experimental values obtained in the laboratory using individual engraulids fed at levels close to satiety (Balbontín et al. 1979, Hunter \& Leong 1981). The daily ration was converted to calories and compared to the results published for other Engraulis species both in natural habitats and in the laboratory, as well as estimates calculated using bioenergetic models. Finally, the daily stomach fullness pattern is also described in the present paper

\section{MATERIALS AND METHODS}

Sampling of anchovies was carried out on the continental shelf in the vicinity of the Ebro River delta from Tarragona to Castellón in the Catalan Sea off the coast of Spain in the NW Mediterranean (Fig. 1) during the species' peak spawning period. The sampling area is a major anchovy spawning area. Spawning commences in April and continues to October, peaking during May and June when $86 \%$ of total spawning takes place (Palomera 1992).

Samples were collected during an acoustic survey carried out on board a commercial trawler from 26 to 30 May 1994. A total of 22 tows were carried out using a midwater trawl net. Anchovies were caught in only 16 of those tows. The tows were performed at different times of day in an endeavour to cover the entire diel cycle. Trawling depth varied but was generally shallower at night, when fish-finding equipment detected shoals closer to the surface than during daytime. Mean surface water temperature during sampling was $20.7^{\circ} \mathrm{C}$. Table 1 presents the data on the tows in which 
anchovies were taken and on the corresponding samples.

Individuals were fixed immediately in 10\% formalin. Individual size (to the nearest $1 \mathrm{~mm}$ ), total body weight (BW), and weight of the somatic fraction (to the nearest $0.01 \mathrm{~g})$ were measured 3 mo later in the laboratory. The digestive tract was then removed. Stomachs were dissected and stomach contents dried in an oven at $70^{\circ} \mathrm{C}$ for $48 \mathrm{~h}$. Dry weight (DW) of stomach contents was measured to the nearest $0.001 \mathrm{~g}$. The stomach fullness index for each fixed individual was calculated by dividing the DW of the stomach contents by somatic BW. Wet somatic BW was used instead of total BW to avoid errors stemming from variations in gonad weight during the spawning period. The index was expressed in terms of $1000 \mathrm{~g}$ of somatic BW. A prior analysis of individual weight variations failed to disclose any significant differences between fixed specimens and fresh specimens (I. R. Torres pers. comm.), hence no correction factor was applied to the weight values. Regurgitation during trawling was not detected since no presence of food was found in the aesophagus.

To calculate daily ration in anchovies we used the exponential model described by Elliott \& Persson (1978). Daily ration was calculated for the $24 \mathrm{~h}$ period with the highest number of anchovy-containing trawls (Table 1).

The Elliott \& Persson (1978) model balance of inputs and outputs in an individual stomach over the time interval $\mathrm{d} t$ is:

$$
\frac{\mathrm{d} S}{\mathrm{~d} t}=A-R S
$$

where $S$ is the amount of food present in the stomach, $A$ is the food ingestion rate, and $R$ is the instantaneous gastric evacuation rate.

Consumption over a given time interval $t$ was described by the equation

$$
C_{t}=\frac{R t\left(S_{t}-S_{0} \mathrm{e}^{-R_{t}}\right)}{1-\mathrm{e}^{-R_{t}}}
$$

where $C_{t}$ is consumption over time $t, S_{t}$ is the mean stomach fullness index over time $t, S_{0}$ is the mean stomach fullness index starting at time 0 , and $R$ is the instantaneous gastric evacuation rate (Elliott \& Persson 1978). Total consumption over an entire cycle $\left(C_{T}\right)$ is equal to the sum of partial consumptions calculated for the $n$ time intervals between tows over a complete cycle.

$$
C_{T}=\sum_{1}^{n} C_{t n}
$$

Again based on the exponential model of digestion, Eggers (1979) proposed an alternative to Eq. (2) to calculate consumption over a time interval $t$ :

$$
C_{t}-\left(S_{t}-S_{0}\right)=\bar{S} R t
$$

where $C_{t}$ is consumption over the feeding interval considered, $S_{t}$ is the mean stomach fullness index at the end of the interval, $S_{0}$ is the mean stomach fullness index at the beginning of the interval, $\bar{S}$ is the mean stomach fullness index over the entire interval, $R$ is the instantaneous evacuation rate, and $t$ is interval dura-

\begin{tabular}{|c|c|c|c|c|c|c|c|}
\hline $\begin{array}{l}\text { Sample } \\
\text { number }{ }^{\alpha}\end{array}$ & Location & $\begin{array}{c}\text { Date } \\
\text { (1994) }\end{array}$ & $\begin{array}{c}\text { Mean time } \\
\text { of catch } \\
\text { (h GMT) }\end{array}$ & $\begin{array}{c}\text { Trawling } \\
\text { duration } \\
\text { (min) }\end{array}$ & $\begin{array}{c}\text { Initial } \\
\text { depth } \\
\text { (m) }\end{array}$ & $\begin{array}{c}\text { Sample } \\
\text { size } \\
\text { (ind.) }\end{array}$ & $\begin{array}{c}\text { Average } \\
\text { length } \\
\text { (mm) }\end{array}$ \\
\hline 2 & $40^{\circ} 52.07^{\prime} \mathrm{N}, 1^{\circ} 17.19^{\prime} \mathrm{E}$ & 26 May & $17: 06$ & 89 & 134 & 20 & 127.4 \\
\hline 4 & $40^{\circ} 49.11^{\prime} \mathrm{N}, 1^{\circ} 02.94^{\prime} \mathrm{E}$ & 27 May & $05: 38$ & 45 & 86 & 20 & 112.2 \\
\hline 5 & $40^{\circ} 48.80^{\prime} \mathrm{N}, 0^{\circ} 58.90^{\prime} \mathrm{E}$ & 27 May & $07: 25$ & 50 & 80 & 20 & 100.3 \\
\hline 6 & $40^{\circ} 49.01^{\prime} \mathrm{N}, 0^{\circ} 52.20^{\prime} \mathrm{E}$ & $27 \mathrm{May}$ & $09: 59$ & 47 & 46 & 20 & 103.4 \\
\hline 7 & $40^{\circ} 51.22^{\prime} \mathrm{N}, 0^{\circ} 54.30^{\prime} \mathrm{E}$ & 27 May & $16: 10$ & 40 & 71 & 20 & 110.7 \\
\hline 8 & $40^{\circ} 52.49^{\prime} \mathrm{N}, 0^{\circ} 54.60^{\prime} \mathrm{E}$ & 28 May & $00: 44$ & 33 & 69 & 17 & 105.8 \\
\hline $9^{\mathrm{b}}$ & $40^{\circ} 40.81^{\prime} \mathrm{N}, 1^{\circ} 01.19^{\prime} \mathrm{E}$ & $28 \mathrm{May}^{\prime}$ & $04: 40$ & 60 & 67 & 20 & 112.3 \\
\hline $10^{\mathrm{b}}$ & $40^{\circ} 36.18^{\prime} \mathrm{N}, 0^{\circ} 57.97^{\prime} \mathrm{E}$ & 28 May & $07: 08$ & 25 & 63 & 20 & 104.6 \\
\hline $11^{b}$ & $40^{\circ} 10.82^{\prime} \mathrm{N}, 0^{\circ} 30.42^{\prime} \mathrm{E}$ & 28 May & $11: 39$ & 58 & 61 & 20 & 104.6 \\
\hline $12^{\mathrm{b}}$ & $40^{\circ} 06.02^{\prime} \mathrm{N}, 0^{\circ} 36.00^{\prime} \mathrm{E}$ & $28 \mathrm{May}$ & $14: 43$ & 45 & 74 & 20 & 125 \\
\hline $13^{b}$ & $40^{\circ} 10.30^{\prime} \mathrm{N}, 0^{\circ} 43.26^{\prime} \mathrm{E}$ & 28 May & $18: 13$ & 55 & 77 & 20 & 121.2 \\
\hline $14^{\mathrm{b}}$ & $40^{\circ} 24.24^{\prime} \mathrm{N}, 0^{\circ} 34.70^{\prime} \mathrm{E}$ & 29 May & $02: 42$ & 24 & 33 & 20 & 97 \\
\hline $15^{b}$ & $40^{\circ} 28.16^{\prime} \mathrm{N}, 0^{\circ} 45.37^{\prime} \mathrm{E}$ & 29 May & $05: 06$ & 52 & 48 & 14 & 104.2 \\
\hline 16 & $40^{\circ} 25.19^{\prime} \mathrm{N}, 1^{\circ} 09.09^{\prime} \mathrm{E}$ & 29 May & $07: 55$ & 30 & 97 & 20 & 113.3 \\
\hline 21 & $40^{\circ} 02.41^{\prime} \mathrm{N}, 0^{\circ} 20.07^{\prime} \mathrm{E}$ & 29 May & $23: 21$ & 59 & 61 & 20 & 105.3 \\
\hline 22 & $40^{\circ} 03.20^{\prime} \mathrm{N}, 0^{\circ} 14.46^{\prime} \mathrm{E}$ & 30 May & $03: 45$ & 60 & 41 & 20 & 107.3 \\
\hline
\end{tabular}
tion. To use Eq. (3) in calculating daily ration, comprehensive sampling is required; in certain cases sam-

Table 1. Sampling information for anchovies used in the diel cycle study 
pling intervals longer than 3 h have been shown to produce substantial errors in the determination (Elliott \& Persson 1978). However, Eq. (4) can be applied when sampling coverage is less extensive and in some cases has been shown to be preferable to Eq. (3) due to its greater robustness to changes in the sampling pattern (Boisclair \& Leggett 1988). We calculated daily ration with both Eqs. (3) $\&(4)$.

The standard error associated with the use of Eqs. (2) \& (3) in computing the daily ration was approximated following the method of Worobec (1984).

The mean stomach fullness data from samples taken during that part of the daily cycle when individuals were assumed not to feed were used to calculate the instantaneous evacuation rate (Arrhenius \& Hansson. 1994). The relationship between the mean stomach fullness index at the end $\left(S_{t}\right)$ and start $\left(S_{0}\right)$ of the said fasting period can be expressed as:

$$
S_{t}=S_{0} \mathrm{e}^{-R t}
$$

Applying natural logarithms to both members of the equation yields the evacuation rate in the form of the slope of the regression line for the natural logarithm of the mean stomach fullness index on time.

The final value of the daily ration expressed in terms of DW of food as a proportion of net BW was converted to energy units on the basis of its caloric content. To this end calorimetric determinations of the food removed from the stomachs of specimens from the 3 samples with the highest mean stomach fullness indices were performed using a Gallemkamp CBB 330 ballistic bomb calorimeter. Fixed food was used because very few, if any, differences have been reported in marine invertebrates between caloric determinations from fixed and fresh animals (Dauvin \& Joncourt 1989),

Food measured in DW was converted to wet weight on the assumption that the diet consisted primarily of zooplankton, applying the water content value for copepods of the genus Calanus reported by Lovegrove (1966), i.e. $84.7 \%$.

\section{RESULTS}

\section{Daily feeding pattern}

The data revealed a pattern of daytime feeding by anchovies with minimum mean stomach fullness indices of 0.001 to $0.012 \mathrm{~g} \mathrm{DW} 1000 \mathrm{~g}^{-1}$ somatic BW from 03:45 to 05:38 h GMT (Greenwich Mean Time).

Stomach fullness index values increased as the day progressed, attaining maximum values of $1.948 \mathrm{~g}$ at 17:06 h GMT and 1.813 g at 18:13 h GMT. Fullness values then declined rapidly again to the nighttime low. Minimum stomach fullness values during the sampling period were recorded around sunrise, which took place at approximately 04:50 h GMT, after which the values quickly rose. Similarly, maximum stomach fullness values were recorded a few hours before sunset, which took place at 19:35 h GMT (Fig. 2).

\section{Calculation of the daily ration}

Before ascertaining the most appropriate statistic for representing stomach fullness in the samples used to determine the daily ration, the data for each sample were tested for normality using the KolmogorovSmirnoff test. At the 5\% level of significance, all the samples were normal except the 2 samples with the lowest stomach fullness values, in which most individuals had empty stomachs. Accordingly, the arithmetic mean of the stomach fullness indices for all the individuals in a sample was regarded as adequately representative of the level of stomach fullness in that sample. Changes in stomach fullness over the daily cycle were considered by applying the Mann-Whitney test to every 2 consecutive samples as a test of the significance of the differences observed. All samples were significantly different from the preceding sample at a significance level of $5 \%$. Multifactorial ANOVAs were also run to detect possible differences in stomach fullness according to sex and size, respectively. To this end, individuals were assigned to $0.5 \mathrm{~cm}$ size classes. No significant differences were found for either of the 2 factors considered at the $1 \%$ level of significance $\left(F_{1.138}=0.63\right.$ for sex and $F_{9133}=2.54$ for size $)$. All 
statistical analyses were performed using the STATGRAPHICS program (STSC 1991).

Consumption was calculated only on the basis of that part of the daily cycle in which individuals were assumed to feed, that is, those samples taken between 04:40 and 18:13 h GMT on 28 May (Fig. 2). This assumption was based on the fact that samples taken after sunrise showed a high degree of digestion of the food bolus. The remaining samples were used to determine the instantaneous gastric evacuation rate on the assumption that between 18:13 and 05:06 h GMT individuals no longer fed but instead evacuated the food ingested earlier.

The instantaneous gastric evacuation rate computed was $R\left(\mathrm{~h}^{-1}\right)=0.423 \pm 0.196$. Calculation of the daily ration according to the method of Elliott \& Persson (1978) using this value of $R$ with estimation of the standard error (SE) as proposed by Worobec (1984) yielded the following result:

$$
C_{t}=6.147 \pm 1.429 \mathrm{~g} \mathrm{DW} 1000 \mathrm{~g}^{-1} \text { somatic BW }
$$

Applying the method of Eggers (1979) for the said feeding period on 28 May yielded a value of $C_{t}=$

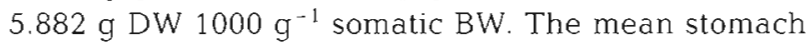
fullness index used in the Eggers (1979) calculation (Eq. 4) was $0.712 \mathrm{~g} \mathrm{DW} 1000 \mathrm{~g}^{-1}$ somatic BW.

The average caloric content of the food present in the stomachs of individuals during the periods of maximum stomach fullness was $5.77 \pm 0.22 \mathrm{kcal} \mathrm{g}^{-1} \mathrm{DW}$ Daily consumption by anchovies expressed as calories was thus:

$$
\begin{aligned}
C_{1}= & 0.0355 \mathrm{kcal} \mathrm{g}^{-1} \text { somatic BW } \\
& (\text { Elliott \& Persson method) } \\
C_{t}= & 0.0339 \mathrm{kcal} \mathrm{g}^{-1} \text { somatic BW } \\
& (\text { Eggers method) }
\end{aligned}
$$

For comparison, the values for total BW were:

$$
\begin{aligned}
C_{t}= & 0.0341 \mathrm{kcal} \mathrm{g}^{-1} \text { total BW } \\
& (\text { Elliott \& Persson method }) \\
C_{t}= & 0.0326 \mathrm{kcal} \mathrm{g}^{-1} \text { total BW } \\
& (\text { Eggers method })
\end{aligned}
$$

The daily ration is often presented in the form of wet weight of food as a percentage of total fresh weight. The values calculated in the present study were:

$$
\begin{aligned}
& C_{t}=3.921 \% \text { of BW (Elliott \& Persson method) } \\
& C_{t}=3.698 \% \text { of BW (Eggers method) }
\end{aligned}
$$

\section{DISCUSSION}

Anchovies in the study area fed during daytime. The studies on feeding carried out in the Black Sea and the Sea of Azov suggested this same daytime feeding pattern. Using data collected at the end of the spawning period (August), Mikhman \& Tomanovich (1977) recorded minimum stomach fullness at around 04:00 h and reported that anchovies did not feed at night. Using qualitative and quantitative data on daily cycles collected in different parts of the Black Sea in May and June (spawning period), Bulgakova (1993a) concluded that the feeding pattern depended upon the population structure of the plankton at any given time. She suggested that feeding takes place in the daytime when the diet is based on large zooplankters that require active predation, while it may take place at any time of day when the diet is based on plankton that can be captured through filtration. Moreover, based on the results of experiments performed on Engraulis capensis in captivity, James \& Findlay (1989) concluded that whether or not individuals opted for active predation did not depend on light conditions but solely on the presence of large zooplankters in the plankton.

The determination of the feeding intensity of European anchovies presented here, which is the first study of its kind carried out in the Mediterranean Sea, differs from that reported for the same species in the Black Sea. The daily ration calculated in this study - less than $4 \%$ of BW - was much smaller than the daily ration of 16 to $23 \%$ calculated by Bulgakova (1993b), also during the spawning period. The difference may be attributable in part to different ecological conditions and hence differences in food availability in the 2 study areas considered. However, the authors consider the instantaneous gastric evacuation rate obtained by on-board experiments employed by Bulgakova (1993b) $\left(R=1.05 \mathrm{~h}^{-1}\right)$ to be excessively high, compared to the values of $R$ found in the scientific literature for other fishes (Durbin et al. 1983, Worobec 1984, Brodeur \& Pearcy 1987, Amundsen \& Klemetsen 1988, Arrhenius \& Hansson 1994); and that value is in large measure responsible for the final results. The findings of experiments aimed at determining gastric evacuation in captive live individuals on board ship or in the laboratory may be quite different from the true value, first due to stress suffered by recently captured individuals and second due to experimental conditions (Bromley 1994). Equations for calculating $R$ as a function of temperature based on available values for different species (Durbin et al. 1983, Worobec 1984) are probably a cruder approximation. The method employed in this study afforded us with the advantage of using unstressed individuals under a natural regime of feeding, though it did present the drawback of not being useful in determining the exact time that feeding ceased or whether or not fasting was total. This could result in a slight underestimation of the diet. The daily ration of 32.6 to $34.1 \mathrm{cal} \mathrm{g}^{-1}$ total BW estimated in this study is in full agreement with the daily rate of con- 
sumption at sea estimated for Engraulis mordax by Hunter \& Leong (1981), allowing for energy expenditures on growth and reproduction, i.e. $348 \mathrm{cal} \mathrm{d}^{-1}$ for an individual weighing $10.3 \mathrm{~g}$, which yields a value of $33.78 \mathrm{cal} \mathrm{g}^{-1}$. It is also close to the value estimated for E. anchoita by Tsukuyama \& Benites (1981), who estimated the daily food ingestion rate at between 34.64 and $44.21 \mathrm{cal} \mathrm{g}^{-1}$ total BW during the spawning period. Based on field samples, Angelescu \& Anganuzzi (1986) calculated a daily ration of $4.5 \% \mathrm{BW}$ for E. anchoita in October, a period of high feeding intensity in that species. That value is likewise close to our estimate for $E$. encrasicolus.

Experimental studies on feeding in species of the genus Engraulis have contributed interesting data on the plasticity of the daily ration and its adaptability to food availability in the habitat. Thus, consumption rates of $124 \mathrm{cal} \mathrm{g}^{-1}(16 \% \mathrm{BW})$ in E. mordax (Hunter \& Leong 1981) and $12 \% \mathrm{BW}$ in E. ringens (Balbontín et al. 1979 ) have been reported. Similar findings were reported by Sirotenko \& Danilevskiy (1978) for $E$. encrasicolus in the Black Sea; those workers explained that the plasticity of the diet is a means of optimizing and maximizing periods of high production, storing energy in the form of fats. In that geographical region, autumn is the period when fat deposits are laid down (Shul'man 1957). This contrasts with the Alborán Sea in the western Mediterranean, where fat reserves are accumulated chiefly in spring (Fernández \& del Val 1960). Both the plasticity of the daily ration depending on food availability and possible differences in ecological strategies might be partly responsible for the discrepancy between our results and the findings reported by Bulgakova (1993b) in the Black Sea.

Study of the feeding intensity of European anchovies should be undertaken over all annual cycles and in different ecologically well-defined geographical areas. Studying changes in feeding intensity together with monitoring sizes of fat reserves and gonadal development, also taking growth into account, would help elucidate the relationship between these phenomena, the extent to which reproductive processes depend on the amount of food ingested during the spawning period and the extent to which reproductive processes depend on available energy reserves.

Acknowledgements. This research has been supported by a grant of the CIRIT (Catalonian Public Agency of Research). Sampling was obtained through the CE Project (Ref. AIR1CT92-0314). The authors are grateful to M. Perelló, skipper of the trawler, and his team. R. Torres Villegas helped with sampling on board. J. B. Company kindly contributed in the calorimetric analysıs of gut contents. F. Sardà made valuable comments on the original manuscript.

\section{LITERATURE CITED}

Amundsen PA, Klemetsen A (1988) Diet, gastric evacuation rates and food consumption in a stunted population of Artic charr, Salvelinus alpinus L., in Takvatn, northern Norway. J Fish Biol 33:697-709

Angelescu $V$, Anganuzzi A (1986) Ecologia trófica de la anchoita (Engraulidae, Engraulis anchoita) del mar argentino. Parte III: Requerimiento trófico individual en relación con el crecimiento, ciclo sexual y las migraciones estacionales. Rev Invest Des Pesq 5:194-224

Arrhenius $F_{1}$ Hansson $S$ (1994) in situ food consumption by young-of-the-year Baltic Sea herring Clupea harengus: a test of predictions from a bioenergetics model. Mar Ecol Prog Ser 110:145-149

Bajkov AD (1935) How to estimate the daily food consumption of fish under natural conditions. Trans Am Fish Soc 65: 288-289

Balbontín F, Garreton M, Mureira J (1979) Estudio experimental sobre selección de alimento y comportamiento alimentario en anchoveta y sardina de Chile. (Pisces, Clupeiformes). Rev Biol mar 16(3):211-220

Boisclair D, Leggett WC (1988) An in situ experimental evaluation of the Elliott and Persson and Eggers models for estimating fish daily ration. Can J Fish Aquat Sci 45:138-145

Brodeur RD, Pearcy WG (1987) Diel feeding chronology, gastric evacuation and estimated daily ration of juvenile coho salmon, Oncorhynchus kisutch (Walbaum), in the coastal marine environment. J Fish Biol 31:465-477

Bromley P (1994) The role of gastric evacuation experiments in quantifying the feeding rates of predatory fish. Rev Fish Biol Fish 4:36-66

Bulgakova YU (1993a) Daily feeding dynamics of the Black Sea anchovy, Engraulis encrasicolus. J Ichthyol 33(7):78-88

Bulgakova YU (1993b) Intensity of feeding of the Black Sea anchovy, Engraulis encrasicolus, during the spawning period. J Ichthyol 32(7):146-151

Dauvin JC, Joncourt M (1989) Energy values of marine benthic invertebrates from the western English Channel. J mar biol Ass UK 69:589-595

Durbin EG, Durbin AG, Langton RW, Bowman RE (1983) Stomach contents of silver hake, Merluccius bilinearis, and Atlantic cod, Gadus morhua, and estimation of their daily rations. Fish Bull US 81(3):437-454

Eggers DM (1979) Comments on some recent methods for estimating food consumption by fish. J Fish Res Bd Can 36: 1018-1019

Elliott JM, Persson L (1978) The estimation of daily rates of tood consumption for fish. J Anim Ecol 47:977-993

Fernández R, del Val MJ (1960) Estudio preliminar sobre la biometría, biología y variación del contenido graso del boquerón (Engraulis encrasicholus (L.)) de Málaga. Boln Inst esp Oceanogr 99:1-28

Hunter JR, Leong R (1981) The spawning energetics of female northern anchovy, Engraulis mordax. Fish Bull US 79(2): 215-230

James AG, Findlay KP (1989) Effect of particle size and concentration on feeding behaviour, selectivity and rates of food ingestion by the Cape anchovy Engraulis capensis. Mar Ecol Prog Ser 50:275-294

Lovegrove $T$ (1966) The determination of the dry weight of plankton and the effect of various factors on the values obtained. In: Barness $H$ (ed) Some contemporary studies in marine science. Hafner, New York, p 429-467

Mikhman AS, Tomanovich LV (1977) The feeding of the Azov anchovy, Engraulis encrasicholus maeoticus. J Ichthyol 17: $240-244$ 
Nikitin VN (1946) Feeding of the anchovy (Engraulis encrasicolus L.) along the Georgian coast of the Black Sea. Trudy Zool Inst Gruz 6:1-64

Okul AV (1941) Feeding of planktivorous fishes in the Sea of Azov. Zool Zh 20(4-5):587-603

Palomera 1 (1992) Spawning of anchovy Engraulis encrasicolus in the Northwestern Mediterranean relative to hydrographic features in the region. Mar Ecol Prog Ser 79 $215-223$

Shul'man GY (1957) Peculiarities of the chemical composition of the Azov anchovy during the period of the spring and wintering migrations. Rybn Khoz 8:68-70

This article was submitted to the editor
Sirotenko MD, Danilevskiy NN (1978) Quantitative feeding indices of the Black Sed anchovy, Engraulis encrasicolus ponticus. J Ichthyol 17(4):610-617

STSC (1991) STATGRAPHICS. Statistical Graphics Corporation, Version 5. STSC, Inc, New York

Tsukuyama I, Sánchez de Benites G (1981) Estimación del consumo de alimento en anchovetas adultas. Boln lnst Mar Perú Ext Vol, p 254-257

Worobec MN (1984) Field estimates of the daily ration of winter flounder. Pseudopleuronectes americanus (Walbaum) in a southern New England salt pond. J exp mar Biol Ecol $77: 183-196$

Manuscript first received: March 20, 1995

Revised version accepted: June 19, 1995 